\title{
THE EFFECTS OF CORPORATE GOVERNANCE \\ ON THE PROFITABILITY OF COMPANIES IN THE FIELD OF PUBLIC WATER SUPPLY SERVICES IN THE REPUBLIC OF MOLDOVA
}

\author{
Ana TIMUS ${ }^{1}$, PhD in Economy, \\ State University of Moldova
}

DOI: https://doi.org/10.36004/nier.es.2020.2-06

JEL Classification: D22, G3, H2, H71, H76, L32, L95, M14

UDC: 338.465(478)

\section{ABSTRACT}

In the Republic of Moldova, in the field of public water supply services, corporate governance, from a conceptual and regulatory point of view, began to develop only in the early 2010s. The selected topic is current because corporate governance is at the early stage in this field, but, at the same time, its evolution for 10 years needs to be analyzed. This process must be monitorized to identify the most important successes or deficiencies in order to develop a set of good practices. The purpose of the research is to identify the relationship between degree of development of corporate governance and the profitability of companies in the field as well as shaping the corporate governance model. Research methods used refer to the observation of corporate and economic processes, interview, investigation, comparing, analysis of corporate legislative and regulatory documents in the field, induction, explanation and interpretation of the main indicators of corporate management. The relevant research results are: identifying the fact that there is no clear dependence between the application of corporate management and increasing the profitability of water companies; at the same time, it has been identified that the participation of employees of water companies in the company boards contributes to better profitability. The corporate governance model was configured, with the identification of deficiencies in the process of regionalization of services. Corporate governance, in the analyzed field, must be subjected of the process of continuous improvement in particular by evaluating the activity of the company's board.

Keywords. Joint stock company, corporate governance, company board, profitability, executive body, stakeholders.

In Republica Moldova, în domeniul serviciilor publice de alimentare cu apă, guvernanța corporativă, din punct de vedere conceptual și reglementar, a început a se definitiva abia la începutul anilor 2010. Tema selectata este actuală deoarece guvernanța corporativă în domeniul selectat este la început de cale, dar în același timp evoluția ei timp de 10 ani necesită a fi analizată pentru identificarea celor mai importante succese sau deficiențe, cu scopul de a elabora un set de bune practici. Scopul cercetării este de a identifica relația dintre gradul de dezvoltare a guvernanței corporative și rentabilitatea companiilor din domeniu precum și conturarea modelului de administrare corporativă. Metodele de cercetare utilizate se referă la observația proceselor corporative și economice, interviu cu actorii implicați, ancheta, comparația, analiza documentelor legislative și de reglementare corporativă din domeniu, inducția, explicarea și interpretarea principalelor indicatori ai managementului corporativ. Rezultatele relevante ale cercetării se rezuma la identificarea faptului că nu există o dependență clara dintre aplicarea managementului corporativ și creșterea profitabilității companiilor de apă; în același timp s-a identificat faptul că participarea în consiliile societății a angajaților companiilor de apă contribuie la o rentabilitate mai bună, s-a configurat modelul de administrare corporativă, cu identificarea deficienților în proces de regionalizare a serviciilor. Guvernanța corporativă, în domeniul analizat, trebuie supusă unui proces de îmbunătățire continuă, în special prin evaluarea activității consiliului societății.

Cuvinte-cheie: societatea pe acțiuni, guvernanță corporativă, consiliul societății, profitabilitate, organul executiv, părțile interesate.

1ID ORCID: 0000-0002-3624-3130, « e-mail: ana.timus.12345@gmail.com

December No. 2/2020 
В Республике Молдова, в сфере услуг общественного водоснабжения, корпоративное управление с концептуальной и нормативной точки зрения появилось только в начале 2010-х годов. Выбранная тема актуальна, потому что корпоративное управление находится в начале пути в этой сфере, но в то же время необходимо проанализировать эволюцию за 10 лет. Нужно осуществлять мониторинг этого процесса, чтобы определить наиболее важные успехи или недостатки для разработки набора хороших практик. Цель исследования - выявить взаимосвязь между степенью развития корпоративного управления и прибыльностью компаний в данной сфере, а также формирование модели корпоративного управления. Используемые методы исследования включают наблюдение за корпоративными и экономическими процессами, интервью, опрос, сравнение, анализ корпоративныхзаконодательных и нормативных документов в этой области, индукция, объяснение и интерпретация основных показателей корпоративного управления. Результаты исследования сводится к: выявление того факта, что нет четкой зависимости между применением корпоративного управления и повышением прибыльности водохозяйственных компаний; В то же время было установлено, что участие сотрудников компаний водоснабжения в советах директоров компаний способствует повышению прибыльности. Была идентифицирована модель корпоративного администрирования с выявлением недостатков в процессе регионализации услуг. Корпоративное управление в анализируемой области должно подвергаться процессу постоянного совершенствования, в частности путем оценки деятельности совета директоров компании.

Ключевые слова. Акционерное общество, корпоративное управление, правление компании, рентабельность, исполнительный орган, заинтересованные стороны.

\section{INTRODUCTION}

Corporate governance is a concept that has been increasing concerned public water supply companies lately. Corporate management provides a greater degree of guarantee that an effective control system is implemented at the company level, thus ensuring that the company is managed in the interests of consumers, local government - owners and other stakeholders.

The concept of "corporate governance" is defined by the Organization for Economic Development and Cooperation as the system of administration and control of companies, totality of a company's relations with its shareholders, or, in the extended sense, with its partners (creditors, suppliers, customers, employees and administrative authorities). It involves a complex system of rights, obligations, attributions and control measures established in order to protect shareholders and investors, they are viewed as a community, and to ensure the liability of administrators and managers towards shareholders [Iovu, 2019:3].

Corporate governance of water companies divides the rights and responsibilities between the various participants in the management of public water supply services and specifies the rules and procedures for making the right decisions for the entity, so as to ensure the right of access to quality services in accordance with the legislation in force and to manage the system at the level of costs, which fall within the limits of the degree of affordability of the tariff. The main objectives of corporate governance within water companies are to create an effective system. to ensure the safety of the infrastructure that was transmitted in management of the water company by the shareholders and its efficient operation complying with regulations and technical requirements in force, including those for environmental protection.

The evolution of the economic and financial results of the water companies in dependence of the corporate governance must be seen in the context of the tendencies of the field of economic activity at national level.

Thus, the evolution in the Republic of Moldova of the Gross Domestic Product for economic activity $E$ Water distribution; sanitation, waste management, decontamination activities, recorded an increase from 1225527 thousand MDL in 2010 to 3303739 thousand MDL in 2018, or an increase of 2.7 times increase in 8 years. (Figure 1) The most remarkable growth was recorded in 2011 compared to 2010 with $48.4 \%$, followed by a period of slow growth 2012-2016, while in 2017 and 2018 the growth becomes more pronounced by $12.4-12.2 \%$ per year. 


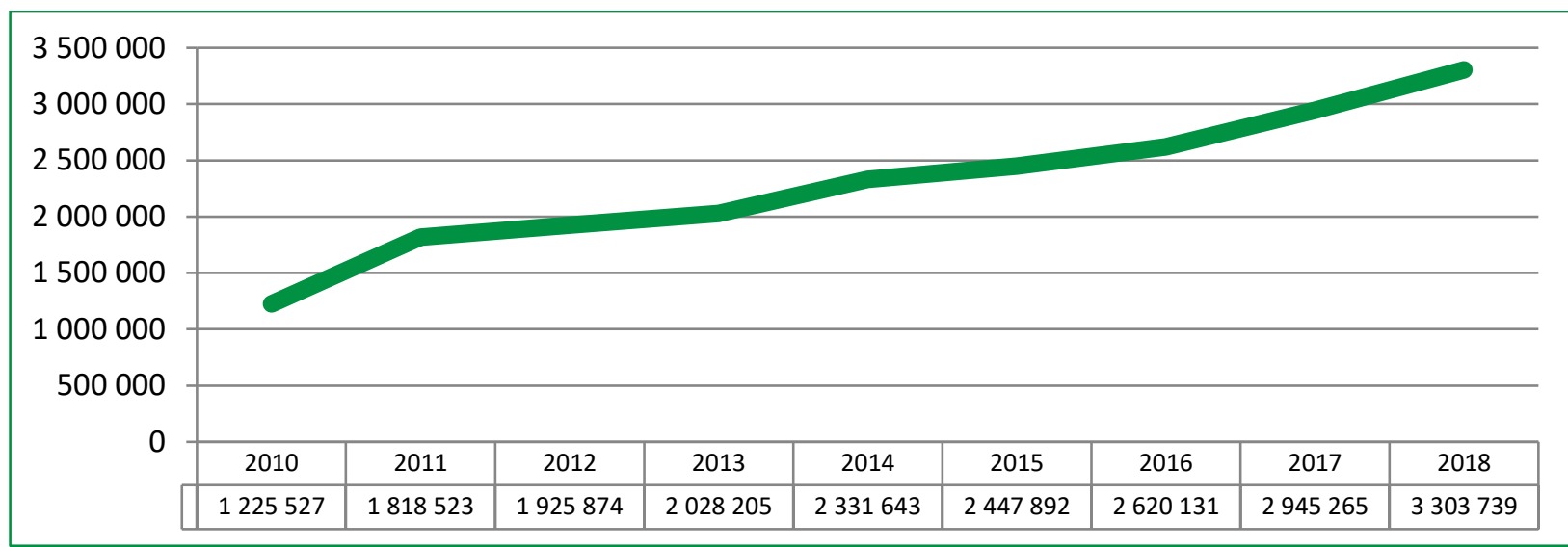

Figure 1. Gross Domestic Product for economic activity: $E$ Water distribution; sanitation, waste management, decontamination activities, thousand MDL

Source: Developed by the author based on [statistica.gov.md].

The contribution of this economic activity to the formation of the Gross Domestic Product, at national level, varied from $0.8 \%$ in 2010 to $1.1 \%$ in 2018 .

Corporate governance for public water supply companies is a new issue, that has been developing slowly lately. The implementation, of corporate governance principles, was recommended to companies in the field by external financing partners. The most remarkable project for this purpose was "The Program for Development of Water Supply and Sewerage Companies", which is the first project with a regionalization component of water supply and sewerage services in the Republic of Moldova. The project, with a worth of 30mil. Euro, was financed by: the European Bank for Reconstruction and Development (EBRD), the European Investment Bank (EIB) and the Neighborhood Investment Fund (NIF).

The general objective of the Project was to promote a reform of water companies by creating sustainable models of operators who will provide services at acceptable standards. The purpose of the Project was to reform the water supply and sewerage services on the territory of the Republic of Moldova and, in particular, to improve and increase the efficiency of water supply services. The mentioned purpose was to be achieved by building and renovating water supply and sewerage systems in 6 regions of the Republic of Moldova, two from each development area of the country: South - Leova and Ceadîr-Lunga; Center - Orhei and Hincesti; North - FloreSti and Soroca. The beneficiary localities have assumed a series of commitments, including the reorganization of water companies into joint stock companies and the application of corporate governance [Decision of the Court of Accounts no. 29, 22.07.2016:4].

Water companies with the form of organization - joint stock companies

Table 1 and the date of reorganization

\begin{tabular}{|c|c|c|c|}
\hline No & Name & $\begin{array}{l}\text { The date on which } \\
\text { the company was } \\
\text { reorganized into JSC }\end{array}$ & Note \\
\hline 1 & J.S.C. "Apa Canal Chișinău" & 1997 & EBRD funded project \\
\hline 2 & J.S.C. „Apă- Canal Leova” & March 11, 2011 & \multirow{5}{*}{$\begin{array}{l}\text { "The Program for } \\
\text { Development of Water Supply } \\
\text { and Sewerage Companies", } \\
\text { funded by EBRD, EIB and NIF }\end{array}$} \\
\hline 3 & J.S.C. „Regia Apă- Canal Soroca” & April 03, 2012 & \\
\hline 4 & J.S.C. „Regia Apă- Canal Orhei” & July 06, 2012 & \\
\hline 5 & J.S.C. „Apă-Termo” Ceadîr-Lunga & November 24, 2010 & \\
\hline 6 & J.S.C. "Operator Regional Apa-Canal" Hincesti & May 19,2011 & \\
\hline 7 & J.S.C. „Servicii Comunale Florești” & May 02,2001 & \\
\hline 8 & J.S.C."Apa Canal Cahul" & April 14, 2017 & $\begin{array}{l}\text { Modernization of Local Public } \\
\text { Services in the RM, GIZ project }\end{array}$ \\
\hline
\end{tabular}

Source: Developed by the author based on [Hotariria Curtii de Conturi nr. 29, 22.07.2016:20]. 
Of all the 8 joint stock companies, only JSC "Servicii Comunale Floresti" was reorganized without this fact being recommended by a financed institution. The shares of these joint stock companies are wholly owned by the local municipal councils.

Out of 40 water supply companies, in urban areas in the Republic of Moldova, only 8 are joint stock companies, the other companies most often have the municipal enterprise form of organization. [AMAC, 2019:8].

This 8 joint stock companies play an important role in the field of public water supply services because they have a turnover that in 2018 was $0.41 \%$ of the national gross domestic product and $50.9 \%$ of the gross domestic product for economic activity. E Water distribution; sanitation, waste management, decontamination activities. The service area, with water supply services of these joint stock companies, covers a population of 1.1 million people, which is $40.9 \%$ of the country's population [statistica.gov.md; AMAC, 2019:14].

\section{The corporate governance model in the public water supply services sector}

Joint stock companies in the field of public water supply services are owned by local public administration, represented by local councils and they can have only an entirely public capital. The corporate governance model of water companies is shown in Figure 2a.

The purpose of reorganizing municipal enterprises into joint stock companies was also the regionalization of water supply services, meaning namely the extension of the service management area of the joint stock company.

Thus, they manage the water supply service in several localities apart from the company's official place of residence. For example, the water company in the town of Florești manages the service in the largest number of localities-27, and the water company from the town of Ceadir-Lunga manages the service only in the city, although it has been transformed into a joint stock company in order to regionalize the service.

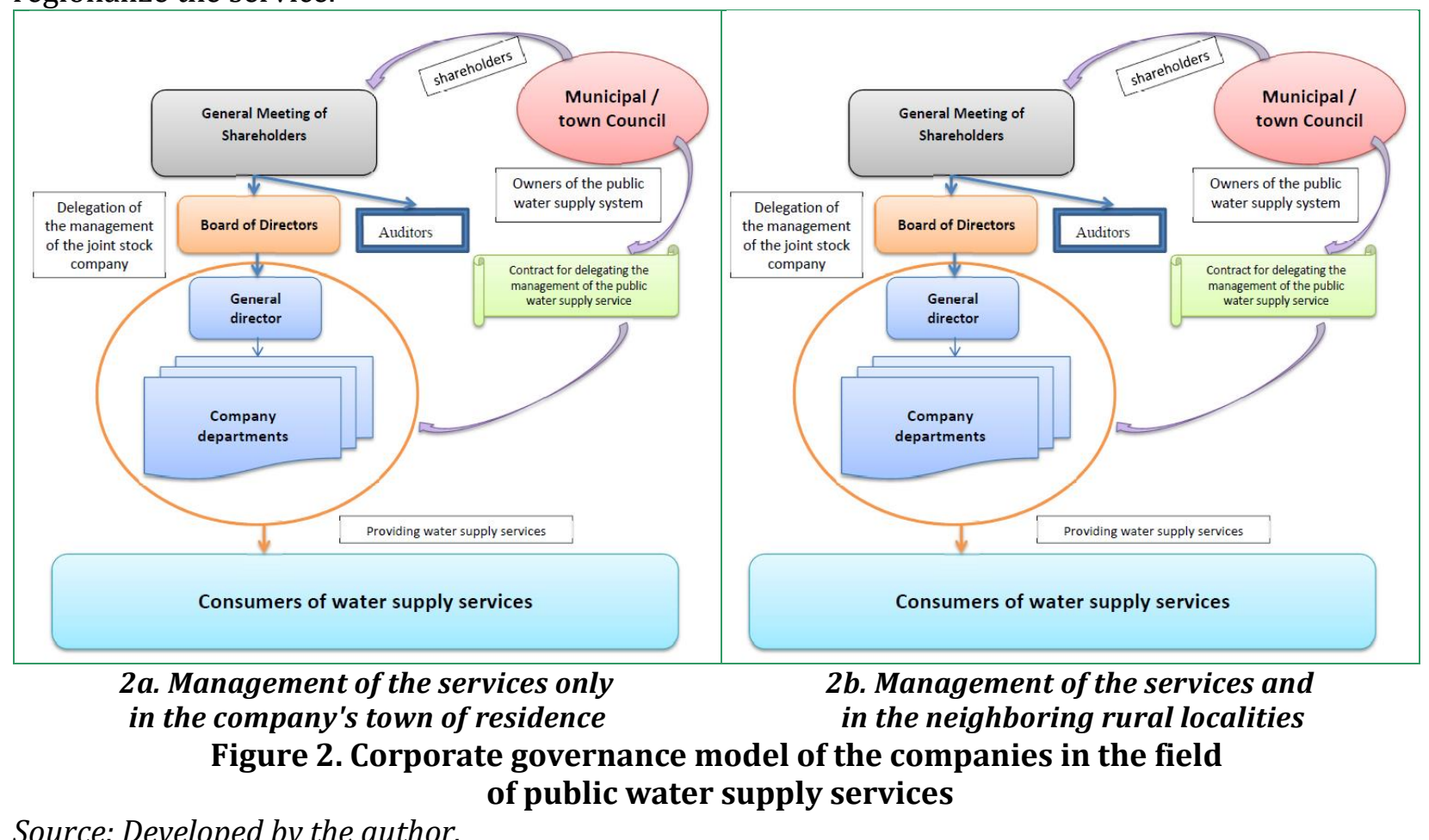

The basic elements of the corporate governance model of water companies in the Republic of Moldova are:

1. The shareholders/general meeting of the shareholders of the joint stock companies in the field of public water supply services are the town/municipal Councils. The new share issues can be offered for subscription only to local authorities from the Republic of Moldova. For all 8 joint stock companies, the decision of the General Meeting of Shareholders is considered the decision taken by 
the Town Council. Within the analyzed joint stock companies, except for JSC "Apa-Canal Chisinau", in most cases, the general meetings of shareholders do not follow the legal procedures of announcement and held, because they take place in the form of meetings of local councils.

2. The company's Board of Directors is elected by the General Meeting of Shareholders and in most cases is composed of local council members. The number of members of the company's board varies from 3 in the case of JSC "Operator Regional Apa-Canal" Hincești to 9 in the case of JSC "Apa Canal Chișinău".

Of the 8 joint stock companies 5 , or $63 \%$ have 5 members on the board of directors of the company. The analysis of the company's board structure identified that most members are local councilmen. There are situations when a representative of the water company is included in the company's board, for example the case of JSC "Apa Canal Chișinău", JSC „Apa-Termo” Ceadîr-Lunga, JSC „Apa- Canal Leova” and JSC “Apa Canal Cahul”.

Table 2

\section{Composition of the Company's Board of Directors}

\begin{tabular}{|c|c|c|c|c|}
\hline No & Name & $\begin{array}{l}\text { Number of } \\
\text { members } \\
\text { on the } \\
\text { company's } \\
\text { board }\end{array}$ & Structure & Chairman \\
\hline 1 & JSC "Apa Canal Chisinău" & 9 & $\begin{array}{l}=5 \text { members delegated by the Local } \\
\text { Public Administration } \\
=4 \text { members delegated by the company }\end{array}$ & No data \\
\hline 2 & JSC „Apa- Canal Leova” & 5 & $\begin{array}{l}=\text { Mayor } \\
=\text { Vice mayor } \\
=1 \text { member delegated by the Local } \\
\text { Public Administration } \\
=2 \text { members delegated by the company }\end{array}$ & Mayor \\
\hline 3 & JSC „Regia Apa- Canal Soroca” & 5 & $=5$ Councillors & Councillor \\
\hline 4 & JSC „Regia Apa- Canal Orhei” & 5 & $=5$ Councillors & Councillor \\
\hline 5 & JSC „Apă-Termo” Ceadiîr-Lunga & 5 & $\begin{array}{l}=2 \text { members delegated by the Bashkan's } \\
\text { (Governor's) office } \\
=1 \text { member delegated by the District } \\
\text { Council } \\
=1 \text { member delegated by the Local Public } \\
\text { Administration } \\
=1 \text { member delegated by the company }\end{array}$ & $\begin{array}{l}\text { Head of the } \\
\text { Economic } \\
\text { Department of } \\
\text { Bașcanat }\end{array}$ \\
\hline 6 & $\begin{array}{l}\text { JSC "Operator Regional } \\
\text { Apa-Canal" Hincesti }\end{array}$ & 3 & $\begin{array}{l}=2 \text { member delegated by the Local } \\
\text { Public Administration } \\
=1 \text { member delegated by the company }\end{array}$ & Councillor \\
\hline 7 & JSC „Servicii Comunale Floresti” & 5 & $=5$ Councillors & Councillor \\
\hline 8 & JSC "Apa Canal Cahul" & 7 & $\begin{array}{l}=5 \text { Councillors } \\
=\text { Chief Accountant of the Town Hall } \\
=1 \text { member delegated by the company }\end{array}$ & Councillor \\
\hline
\end{tabular}

Source: Developed by the author based on [http://ceadir-lunga.apacanal.md; http://floresti.apacanal.md, http://hincesti.apacanal.md; $h$ ttp://leova.apacanal.md; http://www.apacanalcahul.md; http://www.racorhei.md; https://acc.mdceadir-lunga.apacanal.md]

The mandate term of the Company's Board of Directors is 4 years. The selection of the members of the company's board is made by the local councils - the shareholders without the participation of independent experts in the field. The requirements for candidates are vague. A mandate contract is not signed with the company's board, so the board's liability for improper management of the company is not established. The remuneration of the members of the company's board is not related to the fulfillment of performance indicators in the management of the entity.

According to the "best practices" of corporate governance in developed economies, the Board of Directors appoints the chairman from among persons who are not part of the company's 
management. For all analyzed companies, the positions of chairman of the Board of Directors and that of executive director are held by different persons. The implementation of a Code of Ethics is absolutely necessary, according to the "best practices" of governance in developed economies. In the Republic of Moldova, the analyzed joint stock companies do not present information on the existence of a Code of Ethics [Feleaga, 2011:7].

3. The company's Board of Directors delegates the management of the company to the company's executive bodies.

The 7 joint stock companies out of 8, with the exception of JSC "Apa-Canal Chisinau" are managed by a director. In the Articles of Association of a Company of JSC "Apa-Canal Chisinau", it is provided that the executive bodies are the Management Committee and the General Director. They act on behalf of the company for the current production and investment management, in accordance with current legislation, decisions of General Shareholders' Meetings, Board of Directors, the Regulation on the activity of the executive bodies of the JSC "Apa-Canal Chisinau" etc. [Statutul SA "Apa-Canal Chișinau", 6].

The Audit Committee exercises the control of the economic and financial activity of the company. The Audit Committee is obliged to supervise the management of the company, to verify if the financial statements and registers are legally prepared, and whether the evaluation of the patrimonial elements was done according to the rules established for preparing and presenting the financial statements. [Statutul SA "Apa-Canal Chisinau", 16].

In order to be considered effective, corporate governance must provide for appropriate control mechanisms, which will intervene in critical situations and protect the interests of all actors involved. During the research, the presentation of the audit reports on the company's website was analyzed. Only JSC "Apa Canal Chisinau" presented the audit report for 2018 and complied with the information dissemination requirements. JSC „Apa- Canal Leova” presented the audit report for 2016. The other joint stock companies did not present the audit reports on their websites. JSC "Servicii Comunale Floresti" published a news item regarding the audit, but the report was not published. Only JSC "Apa Canal Chisinau" complies with the established information dissemination requirements.

4. The contract for delegating the management of public water supply services. The administrative-territorial units, through the local public administration authorities, delegate the management of their water supply services to the water company through a management delegation contract.

The delegation contract sets out the specific obligations and rights of each party with regard to the investment programs and the achievement of pre-established levels of performance of services. Thus, the water company is responsible for the administration, operation, maintenance, improvement, renewal and extension, where appropriate, of all fixed assets subject to the contract. The most important risk assumed by the company are failure of payment by service customers, according contractual provisions.

Ownership of public assets and the supply of services at affordable costs are the responsibilities of the local public administration. Public assets remain in public ownership and must be taken over by their owner (administrative-territorial units) upon termination of contract. The delegation contract is a longterm commitment [Haskoning Romania, 2008:8-10].

5. Analysis of the evolution of profitability indicators depending on corporate governance issues of joint stock companies in the public water supply services sector

A primary goal of corporate management is to increase the performance of water companies. The instruments of systemic evaluation of the economic efficiency of the corporate governance are in the development phase. Traditional methods to evaluate the economic efficiency of management for water companies are not applicable, because water companies operate under a natural monopoly, the number of customers is limited by the area of service, shareholders can become only territorial administrative units, setting tariffs for services is limited by the ability to pay of the household customers, company assets, mostly have a high degree of wear and require significant maintenance costs, etc. Therefore, scientific research dedicated to solving this difficult problem is highly topical. It is important to point out that joint stock companies in the field of water, appeared not as a result of the evolution of individual business, but as a result of the reorganization of municipal enterprises, which leaves its mark on the efficiency of economic activity of these companies. 


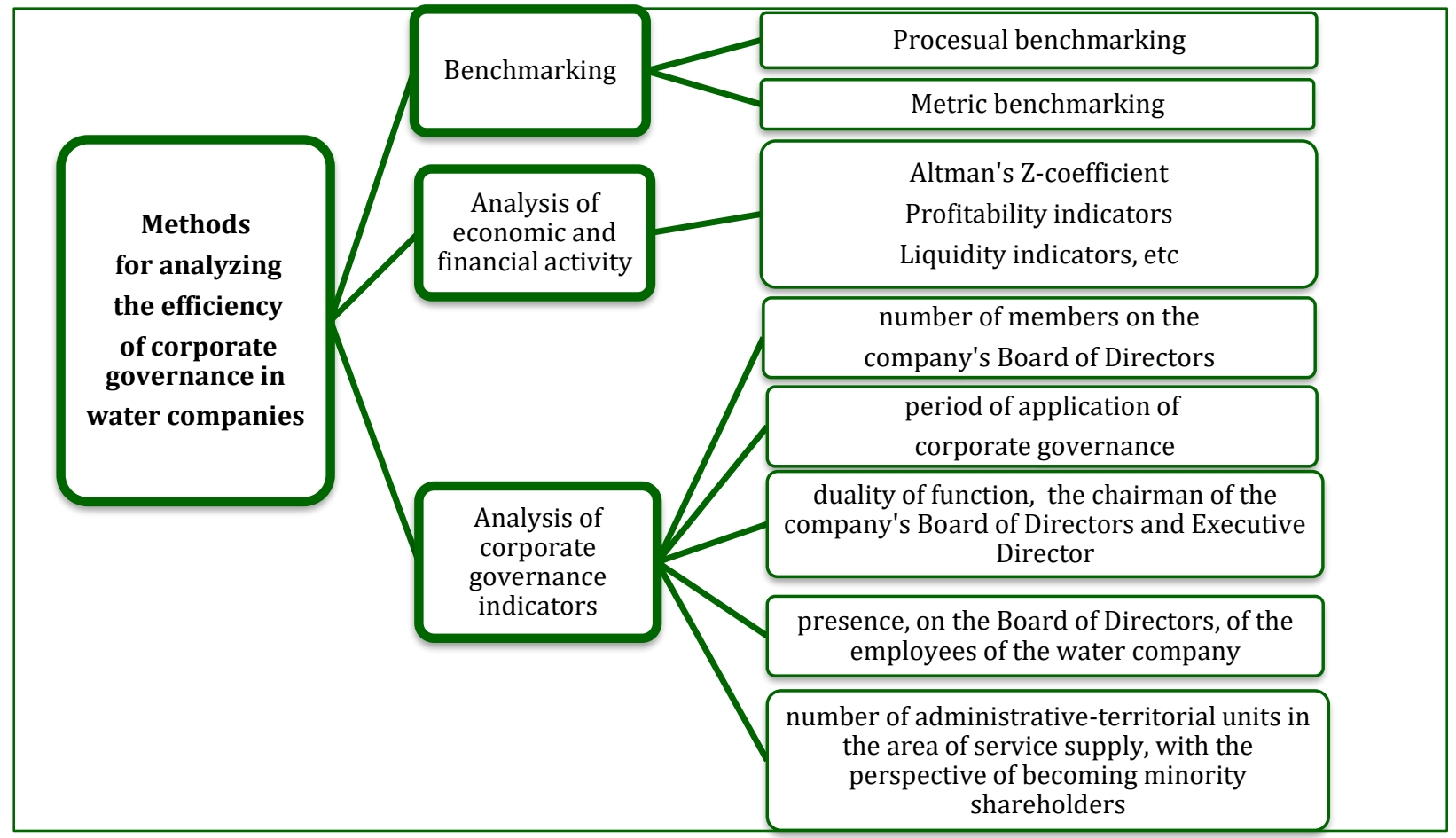

Figure 3. Methods for analyzing the efficiency of corporate governance of joint stock companies in the field of public water supply services

Source: Developed by the author based on [Bocanete, 2013:114].

The analysis of the efficiency of corporate governance of water companies can be done through several methods, the most important of which are presented in Figure 3. From the multitude of approaches, the author selected, by prioritization, a limited number of indicators specific to corporate governance and economic analysis. The summary of the indicators specific to corporate governance analyzed in the previous subchapter is presented in Table 3.

Table 3

The indicators specific to corporate governance of water companies

\begin{tabular}{|c|c|c|c|c|c|c|c|}
\hline 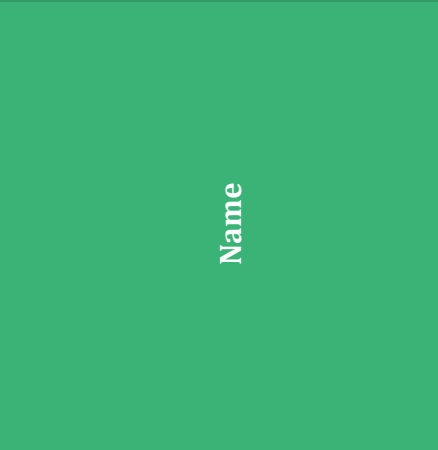 & 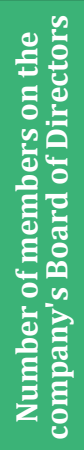 & 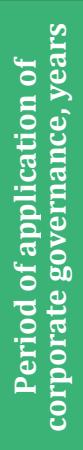 & 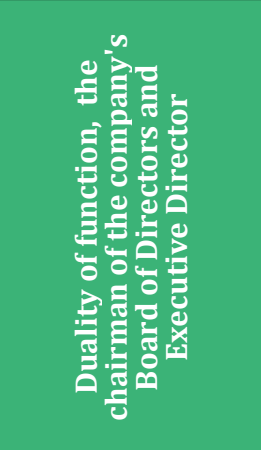 & 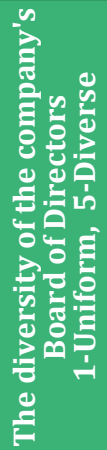 & 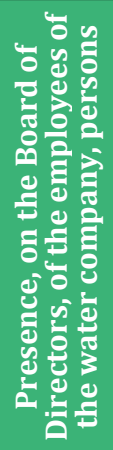 & 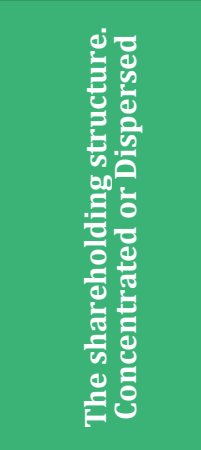 & 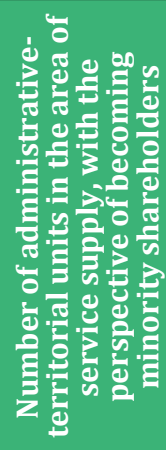 \\
\hline JSC "Apa Canal Chișinău" & 9 & 23 & no data & 4 & 4 & Concentrated & 24 \\
\hline JSC „Apă- Canal Leova” & 5 & 9 & not the same person & 4 & 2 & Concentrated & 2 \\
\hline JSC „Regia Apă- Canal Soroca” & 5 & 8 & not the same person & 1 & 0 & Concentrated & 4 \\
\hline JSC „Regia Apă- Canal Orhei” & 5 & 8 & not the same person & 1 & 0 & Concentrated & 5 \\
\hline JSC „Apă-Termo” Ceadîr-Lunga & 5 & 10 & not the same person & 5 & 1 & Concentrated & 0 \\
\hline $\begin{array}{l}\text { JSC "Operator Regional Apa- } \\
\text { Canal" Hîncești }\end{array}$ & 3 & 9 & not the same person & 4 & 1 & Concentrated & 4 \\
\hline JSC „Servicii Comunale Florești” & 5 & 19 & not the same person & 1 & 0 & Concentrated & 27 \\
\hline JSC "Apa Canal Cahul" & 7 & 3 & not the same person & 4 & 1 & Concentrated & 8 \\
\hline
\end{tabular}

Source: Developed by the author based on [http://ceadir-lunga.apacanal.md;

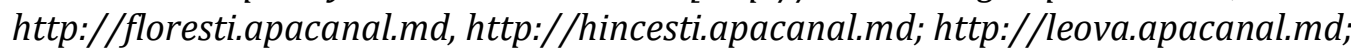
http://www.apacanalcahul.md; http://www.racorhei.md; https://acc.mdceadir-lunga.apacanal.md] 
Another indicator, that reflects the efficiency of corporate governance, refers to the economic and financial activity namely at the evolution of the profitability of water companies. The analysis of the dynamics has the year preceding the reorganization of the municipal enterprise into a joint stock company as a reference point. The subsequent period represents the period of corporate governance of water companies. Considering that after the reorganization of the companies, between 3 to 23 years have passed, it is opportune to analyze the evolution of profitability indicators. Because JSC "Apa Canal Chisinau” with 23 years, JSC „Servicii Comunale Floresti” with 19 years and JSC "Apa Canal Cahul" with 3 years of corporate governance are examples of extremes, these companies were excluded from the analysis due to the fact that they are not representative for the present study.

A key indicator in any economic analysis is turnover. This is considered a fundamental indicator of the volume of a company's activity and, obviously, it is always taken into account when evaluating an entity.

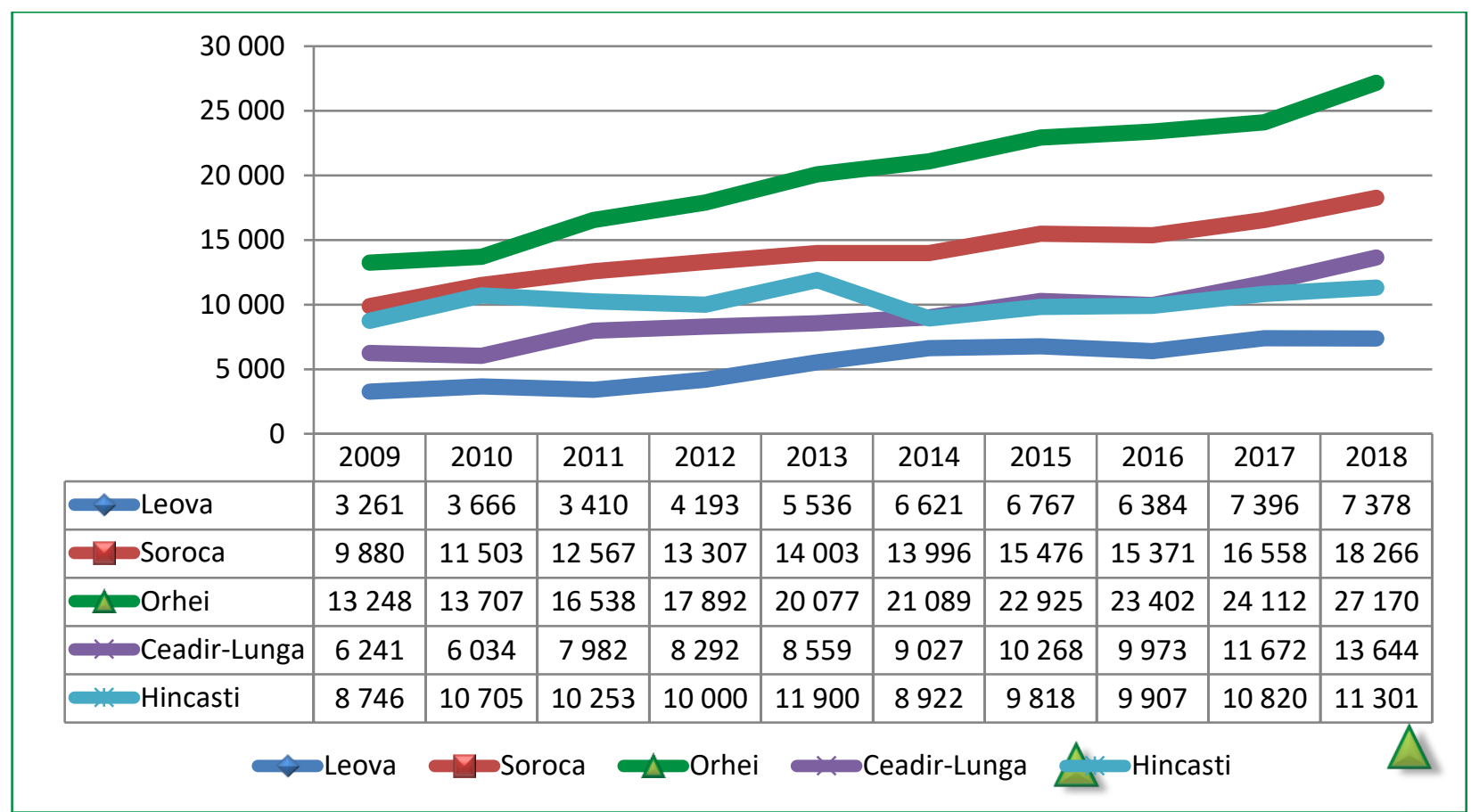

Figure 4. Evolution of turnover after the reorganization of water companies, thousand MDL Source: Developed by the author based on [AMAC, 2019; AMAC, 2018; AMAC 2017; AMAC, 2012; AMAC, 2011; AMAC, 2010].

The turnover of the companies had an increasing trend during the analyzed period, with one exception for JSC "Operator Regional Apa-Canal" Hincești in 2014 compared to 2013. The most accentuated growth was noticed at JSC „Regia Apa-Canal Orhei”, Figure 4.

JSC "Apa-Canal Leova" was reorganized into a joint stock company in 2011, from this year the company applied corporate governance. In the 2012-2018 period, the turnover tended to grow slowly, from 4.2 million MDL in 2012 to 7.4 million MDL in 2018, or by $76.2 \%$ in 6 years. In 2012, 2013 and 2014 the growth rate of turnover is higher compared to the growth rate of Gross Domestic Product for the field of activity of which the company is part.

JSC „Regia Apa- Canal Soroca” was reorganized into a joint stock company in 2012. The 20132018 period is characterized by the increase of the value of the indicator from 14.0 million MDL in 2013 to 18.3 million MDL in 2018, or by 30.7\% in 5 years. In 2012, 2013 and 2015, the growth rate of turnover is equal compared to the growth rate of Gross Domestic Product for the field of activity of which the company is part. For the rest of the years, the growth rate is slower.

JSC „Regia Apa- Canal Orhei” started to apply corporate governance in 2012. Starting with 2013, turnover had an increasing trend. In 2018, a indicator value was 27.2 million MDL, an increase 
compared to 2013 with 36\% in 5 years. In 2012, 2013, 2015 and 2018 the growth rate of turnover is higher compared to the growth rate of the Gross Domestic Product for the field of activity of which the company is part.

JSC „Apa-Termo” Ceadir-Lunga was reorganized in 2010. Starting with 2011 the indicator evolved positively, with some oscillations such as those in 2016. In 2018 the turnover was 13.6 million MDL, or a 70.4\% increase compared to 2011. In 2015, 2017 and 2018, the growth rate of turnover is higher compared to the growth rate of Gross Domestic Product for the field of activity of which the company is part.

JSC "Operator Regional Apa-Canal" Hincești was reorganized in 2011. The turnover of 11.3 million MDL was in 2018, with 13\% more compared to 2012. In 2014 and 2016 the growth rate of turnover is higher compared to the growth rate of Gross Domestic Product for the field of activity of which the company is part.

Analyzing the average growth rate of turnover per year, it was identified that the best results were obtained by JSC „Apă-Canal Leova” with a value of turnover increase per year of $12.6 \%$, and the weakest results were obtained by JSC "Operator Regional Apă-Canal" Hincești with a value of 2.1\% per year. For the other 3 companies the value of the indicator varies from $6 \%$ to $10 \%$. The results obtained by JSC " Apa-Canal Leova" can also be explained by the fact that this is the smallest company out of the 5 , if we take into account the number of customers and the area of service supply.

The evolution of the profit/loss before tax indicator of the 5 water companies, JSC " Apa-Canal Leova", JSC "Regia Apa -Canal Soroca", JSC „Regia Apă-Canal Orhei”, JSC „Apa-Termo” Ceadîr-Lunga and JSC "Operator Regional Apă -Canal" Hincești is presented in figure 5.

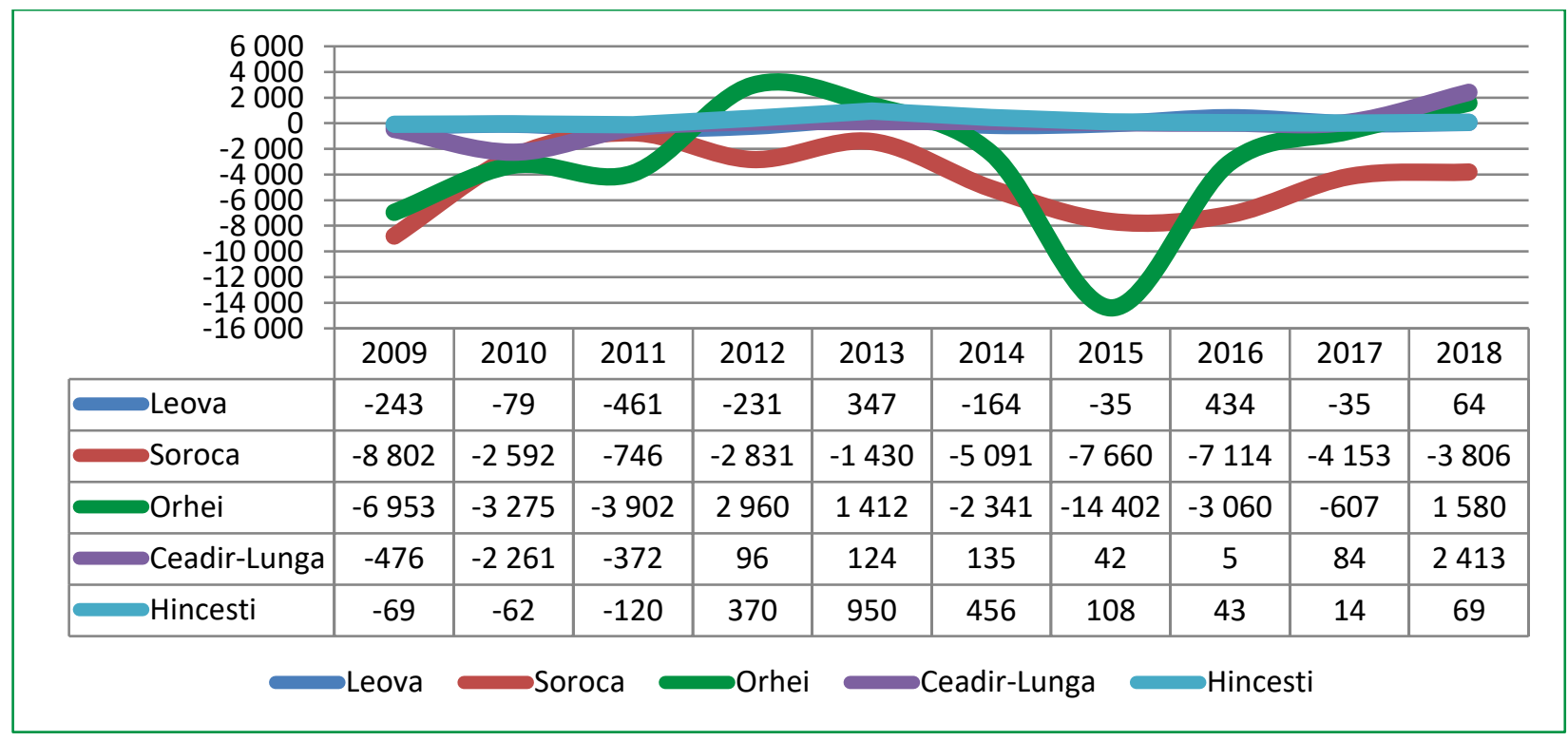

Figure 5. Evolution of profit/loss before tax indicators after the reorganization of water companies, thousand MDL

Source: Developed by the author based on [AMAC, 2019; AMAC, 2018; AMAC 2017; AMAC, 2012; AMAC, 2011; AMAC, 2010].

In most cases, companies recorded losses during the analyzed period, with some exceptions such as 2013, in which 4 out of 5 companies recorded a profit. In the period 2009-2011 all companies recorded losses. Because companies have different sizes, number of customers and areas of operation, a comparative analysis of the indicator between them is not representative, the analysis will focus more on the trend of the indicator for each company and compare the growth rate.

JSC "Apa-Canal Leova" was reorganized into a joint stock company in 2011, the year in which the company recorded the lowest value of the loss indicator. In the period 2012-2018, the value of the indicator registered a slow, oscillating, growth trend, with the maximum value of the profit 434.1 thousand MDL obtained in 2016. 
JSC „Regia Apa- Canal Soroca” was reorganized in the joint stock company in 2012, year in which it recorded a loss of 2831.2 thousand MDL. In the following years of corporate governance of the company, losses were persisted.

JSC „Regia Apa- Canal Orhei” started to apply corporate governance in 2012, year in which it obtained a maximum profit, for the analyzed period. In 2013 and 2018 there was profit, and in the period 2014-2017 there were losses, with a tendency to reduce losses in 2015.

JSC "Apa-Termo" Ceadir-Lunga was reorganized in 2010, a year in which it obtained a record value of losses. Starting with 2011, the indicator evolved positively, in 2018 the profit value was 2413.3 thousand MDL.

JSC "Operator Regional Apa-Canal" Hîncești being reorganized in 2011, recorded only profits in the analyzed period, the values of the indicator are ranging from 13.8 thousand MDL in 2017 to 949.7 thousand MDL in 2013. In the period, 2009-2011, the company recorded losses.

A general feature of the evolution of profit/loss before tax is the fact that compared to the years before the reorganization, in 2018 four of the five companies recorded a profit. A negative aspect in this regard is the fact that this positive result was influenced by the financial activity of the company and not by the operational one.

Taking into account the negative results related to the profitability of companies, it is appropriate to analyze the risk of bankruptcy. One of the best-known quantitative models for predicting bankruptcy was proposed by the economist Altman. It allows to divide the companies into bankruptcy and non-bankruptcy categories.

The Altman indicator is a function of several indicators that characterize the economic potential of the company and the results of its activity in the past period. In general, the solvency indicator (Z- score) could be calculated as follows:

$$
\mathrm{Z}=1,2 \mathrm{X} 1+1,4 \mathrm{X} 2+3,3 \mathrm{X} 3+0,6 \mathrm{X} 4+\mathrm{X} 5
$$

Where:

$\mathrm{X} 1$ - working capital/total assets

$\mathrm{X} 2$ - retained earnings/total assets

$\mathrm{X} 3$ - earnings before interest and tax/total assets

$\mathrm{X} 4$ - market value of equity/total liabilities

$\mathrm{X} 5$ - sales/total assets

A score below 1.8 means it's likely the company is headed for bankruptcy, while companies with scores above 3 are not likely to go bankrupt [Bocanete, 2013:115].

Table 4

Analysis of the company's financial situation based on the Altman model, Z score

\begin{tabular}{|l|c|c|c|}
\hline \multicolumn{1}{|c|}{ Name } & 2016 & 2017 & 2018 \\
\hline JSC „Apă- Canal Leova” & 0.43 & 0.14 & 0.16 \\
\hline JSC „Regia Apă- Canal Soroca” & 0.05 & 0.16 & 0.17 \\
\hline JSC „Regia Apă- Canal Orhei” & 0.14 & 0.24 & 0.31 \\
\hline JSC „Apă-Termo" Ceadîr-Lunga & 0.31 & 0.36 & 0.36 \\
\hline JSC "Operator Regional Apa-Canal" Hincesti & 0.16 & 0.18 & 0.20 \\
\hline
\end{tabular}

Source: Developed by the author based on [AMAC, 2019; AMAC, 2018; AMAC, 2017; AMAC, 2012; AMAC, 2011; AMAC, 2010].

The analysis of the financial situation of water companies based on the Altman model identified that all 5 companies have a $\mathrm{Z}$ score less than 1.8, respectively they are unconditionally insolvent. Table 4. These results have the following aspects as influencing factors: the approved tariffs for the services do not cover the costs, the loans from international financing institutions, the low payment capacity of the customers, etc. A positive issue in the evolution of the $\mathrm{Z}$ score of the Altman model is that, excepting JSC "Apa-Canal Leova", the other four companies had results with a tendency to improve.

Water companies compared to private companies are not effectively influenced by the risk of bankruptcy, because these companies operate under natural monopoly conditions and provide vital services in their operation area and have a crucial role in water protection. For these reasons, a 
precarious economic situation of water companies will lead to subsidizing the activity and not to bankruptcy.

In order to identify the link between corporate governance and the profitability of water companies, the performance of the 5 companies was analyzed in detail, by calculating the profitability indicators, presented in Table 5.

\section{Profitability indicators used in the study}

\begin{tabular}{|l|l|c|}
\multicolumn{4}{|c|}{ Name of the indicator } & \multicolumn{1}{c|}{ Calculation formula } & $\begin{array}{c}\text { Unit of } \\
\text { measurement }\end{array}$ \\
\hline $\begin{array}{c}\text { Profitability from sales revenue calculated on } \\
\text { the basis of profit from operational activity, } \%\end{array}$ & $\begin{array}{l}\text { (Profit from operational activity/ } \\
\text { Sales revenue) } * 100 \%\end{array}$ & $\%$ \\
\hline $\begin{array}{c}\text { Profitability from sales revenue calculated on } \\
\text { the basis of net profit (net loss), } \%\end{array}$ & $\begin{array}{l}\text { (Net profit (net loss)/Sales revenue) } \\
100 \%\end{array}$ & $\%$ \\
\hline
\end{tabular}

Source: Developed by the author based on [AMAC, 2019:40].

The reference year was considered the year before reorganization of the company, and the values of the indicator were analyzed for the previous 3 years, 2016-2018.

Profitability indicators for JSC „Apa-Canal Leova”

\begin{tabular}{|l|c|c|c|c|c|}
\hline \multicolumn{1}{|c|}{ Name of indicators } & $\mathbf{2 0 1 0}$ & $\mathbf{2 0 1 6}$ & $\mathbf{2 0 1 7}$ & $\mathbf{2 0 1 8}$ \\
\hline Sales revenue, thousand MDL & 3665.8 & & 6383.8 & 7396.3 & 7377.7 \\
\hline Profit/ loss from operational activity, thousand MDL & -79.0 & & -202.6 & -1873.2 & -2354.9 \\
\hline Net profit (net loss), thousand MDL & -79.0 & & 369.6 & -35.3 & 64.2 \\
\hline $\begin{array}{l}\text { Profitability from sales revenue calculated on the } \\
\text { basis of profit from operational activity, \% }\end{array}$ & -2.2 & & -3.2 & -25.3 & -31.9 \\
\hline $\begin{array}{l}\text { Profitability from sales revenue calculated on the } \\
\text { basis of net profit (net loss), \% }\end{array}$ & -2.2 & & 5.8 & -0.5 & 0.9 \\
\hline
\end{tabular}

Source: Developed by the author based on [AMAC, 2019; AMAC, 2018; AMAC, 2017; AMAC, 2012; AMAC, 2011].

JSC „Apa-Canal Leova” was reorganized into a joint stock company in 2011. During 2016-2018, sales revenue had a slow growth. The indicator that was recorded in 2018 increased 2 -fold compared to 2010. Factors that contributed to this process were: the increase of the tariff for the services provided by the company since May 2013, the extension of the service supply area, during the analyzed period the company expanded its services in 2 more localities, which contributed to the increase of the billed water volume in 2016 by $29 \%$ compared to 2010 .

The result from the operational activity records losses, which essentially increased - 29-fold in 2018 , compared to 2010. In the year preceding the reorganization, the company recorded a 79 thousand MDL net loss. In the 2016-2018 period, the value of the indicator recorded an increase in 2016 and 2018 with profits and recorded losses in 2017. The net profit of 369.6 thousand MDL obtained in 2016 and the net profit 64.2 thousand MDL obtained in 2018, was influenced by the result from the financial activity, because the company recorded losses from the operational activity. The company obtained 202.6 thousand MDL in 2016 and 2354.9 thousand MDL in 2018 losses from the operational activity, table 6. The indicator Profitability from sales revenue calculated on the basis of profit from operational activity, recorded negative values in the 2016-2018 period as well as in the reference year - 2010. The maximum value of the indicator was obtained in 2018 with -31.9\%, compared to $-2.2 \%$ that was obtained in 2010 .

The Profitability from sales revenue calculated on the basis of net profit (net loss) indicator, recorded more positive results in 2016 and 2018, they were caused by the results of financial activity, namely foreign exchange differences related to long-term credit. 
Table 7

Profitability indicators for JSC „Regia Apa- Canal Soroca”

\begin{tabular}{|l|c|c|c|c|c|}
\hline \multicolumn{1}{|c|}{ Name of indicators } & 2011 & $\mathbf{2 0 1 6}$ & $\mathbf{2 0 1 7}$ & $\mathbf{2 0 1 8}$ \\
\hline Sales revenue, thousand MDL & 12567.4 & & 15371.1 & 16557.9 & 18265.7 \\
\hline Profit/ loss from operational activity, thousand MDL & -1413.1 & & -7453.0 & -5016.4 & -4450.7 \\
\hline Net profit (net loss), thousand MDL & -745.8 & & -7113.6 & -4153.4 & -3806.0 \\
\hline $\begin{array}{l}\text { Profitability from sales revenue calculated on the basis of } \\
\text { profit from operational activity,\% }\end{array}$ & -11.2 & & -48.5 & -30.3 & -24.4 \\
\hline $\begin{array}{l}\text { Profitability from sales revenue calculated on the basis of } \\
\text { net profit (net loss),\% }\end{array}$ & -5.9 & & -46.3 & -25.1 & -20.8 \\
\hline
\end{tabular}

Source: Developed by the author based on [AMAC, 2019; AMAC, 2018; AMAC, 2017; AMAC, 2012].

JSC „Regia Apa-Canal Soroca” was reorganized into a joint stock company in 2012. Sales revenues had an increasing trend in the 2016-2018 period compared to 2011 . Sales revenues had increased by $45.3 \%$ in 2018 compared to 2011 and by $21.8 \%$ in 2016 compared to 2011 . A factor that contributed to the increase was the updating of the service tariff in March 2013. The volume of billed water did not increase significantly. The volume of billed water has increased by $27.5 \%$ in 2018 compared to 2011, including due to the expansion of the service area in 4 localities, as seen in table 7.

The indicator Profitability from sales revenue calculated on the basis of profit from operational activity, recorded negative values in the period 2016-2018 and in the reference year 2011. The lowest point at -8.5\% was in 2016, compared to $-11.2 \%$ in 2011.

The Profitability from sales revenue calculated on the basis of net profit (net loss) indicator, also recorded negative results, from $-5.9 \%$ in 2011 to $-20.8 \%$ in 2018 . The lowest point at $-46.3 \%$ was in 2016 .

Table 8

Profitability indicators for JSC „Regia Apa-Canal Orhei”

\begin{tabular}{|l|c|c|c|c|c|}
\hline \multicolumn{1}{|c|}{ Name of indicators } & 2011 & $\ldots 2016$ & 2017 & 2018 \\
\hline Sales revenue, thousand MDL & 16537.8 & 23401.6 & 24112.2 & 27169.9 \\
\hline Profit/ loss from operational activity, thousand MDL & -5283.3 & -7585.9 & -5754.3 & -3639.4 \\
\hline Net profit (net loss), thousand MDL & -3902.0 & -3060.1 & -606.6 & 1491.0 \\
\hline $\begin{array}{l}\text { Profitability from sales revenue calculated on the basis of } \\
\text { profit from operational activity,\% }\end{array}$ & -31.9 & -32.4 & -23.9 & -13.4 \\
\hline $\begin{array}{l}\text { Profitability from sales revenue calculated on the basis of } \\
\text { net profit (net loss),\% }\end{array}$ & -23.6 & -13.1 & -2.5 & 5.5 \\
\hline
\end{tabular}

Source: Developed by the author based on [AMAC 2019; AMAC 2018; AMAC 2017; AMAC 2012].

The JSC „Regia Apa-Canal Orhei” started to apply corporate governance in 2012. In 2016-2018 there was a significant increase in sales revenue compared to 2011, although the last update of the service tariff was in April 2011. The main factor influencing the indicator was the volume of billed water, which increased in 2018 by $44.8 \%$ compared to 2011 , as seen in table 8.

Profitability indicators have an upward trend. The Profitability from sales revenue calculated on the basis of profit from operational activity indicator, recorded negative values both in the period 2016-2018 and in the reference year 2011. The lowest point at $-32.4 \%$ was in 2016 , compared to $-31.9 \%$ in 2011.

The Profitability from sales revenue calculated on the basis of net profit (net loss) indicator, recorded negative results, with a clear trend of improvement from $-23.6 \%$ in 2011 to $5.5 \%$ in 2018 . This was due to the results from financial activity, namely exchange rate differences for long-term loans obtained by the company from the World Bank and the European Bank for Reconstruction and Development.

JSC „Apa-Termo” Ceadir-Lunga was reorganized in 2010. Starting with 2016, the sales revenue indicator evolved positively, reaching in 2018 a value of 13.6 million MDL, it was 2.2 times more compared to 2009. The tariff for company services was updated in 2015, being contributing factor to the positive evolution of the indicator. Also a determining factor was the volume of billed water, that increased by $42.6 \%$ in 2018, compared to 2009 
Profitability indicators for JSC „Apa-Termo” Ceadir-Lunga

\begin{tabular}{|l|c|c|c|c|c|}
\hline \multicolumn{2}{|c|}{ Name of indicators } & 2009 & $\mathbf{2 0 1 6}$ & 2017 & 2018 \\
\hline Sales revenue, thousand MDL & 6241.0 & & 9973.1 & 11671.7 & 13644.2 \\
\hline Profit/ loss from operational activity, thousand MDL & -890.8 & & -4104.3 & -4274.2 & -3162.9 \\
\hline Net profit (net loss), thousand MDL & 476.1 & & 4.9 & 84.4 & 2413.3 \\
\hline $\begin{array}{l}\text { Profitability from sales revenue calculated on the basis of } \\
\text { profit from operational activity, \% }\end{array}$ & -14.3 & -41.2 & -36.6 & -23.2 \\
\hline $\begin{array}{l}\text { Profitability from sales revenue calculated on the basis of } \\
\text { net profit (net loss), \% }\end{array}$ & 7.6 & 0.05 & 0.7 & 17.7 \\
\hline
\end{tabular}

Source: Developed by the author based on [AMAC, 2019; AMAC, 2018; AMAC, 2017; AMAC, 2010].

The Profitability from sales revenue calculated on the basis of profit from operational activity indicator, oscillated with negative values in 2016-2018 and in the reference year 2009. The lowest point at $-41.2 \%$ was in 2016, compared to $-14.3 \%$ in 2009 , table 9.

Indicator Profitability from sales revenue calculated on the basis of net profit (net loss), obtained positive oscillating results, with a clear trend of improvement from $7.6 \%$ in 2009 to $17.7 \%$ in 2018 . This is due to the results from financial activity in the amount of 5.57 million MDL, namely the exchange rate differences referring to the long-term loans obtained by the company from the European Bank for Reconstruction and Development.

Table 10

\begin{tabular}{|l|c|c|c|c|c|}
\hline \multicolumn{1}{|c|}{ Name of indicators } & $\mathbf{2 0 1 0}$ & $\ldots$ & $\mathbf{2 0 1 6}$ & $\mathbf{2 0 1 7}$ & $\mathbf{2 0 1 8}$ \\
\hline Sales revenue, thousand MDL & 10705.0 & & 9907.2 & 10820.2 & 11300.9 \\
\hline Profit/ loss from operational activity, thousand MDL & -478.9 & & -62.9 & 78 & 68.4 \\
\hline Net profit (net loss), thousand MDL & -61.8 & & 7.6 & 10 & 68.6 \\
\hline $\begin{array}{l}\text { Profitability from sales revenue calculated on the } \\
\text { basis of profit from operational activity, \% }\end{array}$ & -4.5 & & -0.6 & 0.7 & 0.6 \\
\hline $\begin{array}{l}\text { Profitability from sales revenue calculated on the } \\
\text { basis of net profit (net loss), \% }\end{array}$ & -0.6 & & 0.1 & 0.1 & 0.6 \\
\hline
\end{tabular}

Source: Developed by the author based on [AMAC, 2019; AMAC, 2018; AMAC, 2017; AMAC, 2011].

JSC "Operator Regional Apa-Canal" Hîncești was reorganized in 2011. Starting with 2016, the sales revenue indicator evolved positively, reaching a value of 11.3 million MDL in 2018, which is 5.6\% more compared to 2010. The tariff for company services was updated in June 2012.

The Profitability from sales revenue calculated on the basis of profit from operational activity indicator, had an increasing trend compared to 2010. In the 2016-2018 period, the indicator oscillated around 0\%. The maximum value was recorded in 2017 by $0.7 \%$, compared to $-4.5 \%$ in 2010 .

The Profitability from sales revenue calculated on the basis of net profit (net loss) indicator, recorded oscillating results, mostly positive, with a fine improvement trend from $-0.6 \%$ in 2010 to $0.6 \%$ in 2018 , as seen in table 10.

The research results show that the best values of the profitability indicators were recorded for the companies JSC "Operator Regional Apa-Canal" Hîncești, JSC „Regia Apa- Canal Orhei” and JSC „Apa-Termo” Ceadîr-Lunga, which also denotes an efficient activity of corporate governance structures. The Board of Directors of JSC „Regia Apa- Canal Orhei” and JSC „Apa-Termo” Ceadîr-Lunga is composed of 5 members, and the one from JSC "Operator Regional Apa-Canal" Hîncești has 3 members. Within the company's Board of Directors of the JSC "Operator Regional Apa-Canal" Hîncești and JSC „Apa-Termo” Ceadîr-Lunga are also of the employees of the water companies, which essentially contributes to increasing the efficiency of the company's corporate governance. Out of the 3 nominated companies, 2 are companies that provide services in additional localities than the reference one. JSC "Operator Regional Apa-Canal" Hîncești is a regional operator for additional 4 locations, and JSC „Regia Apa- Canal Orhei” for an additional 5 localities.

The leader, based on the analyzed indicators, is JSC "Operator Regional Apa-Canal" Hincesti, which 
managed to improve even the profitability of the operational activity, evolving from negative to positive values. JSC „Regia Apa-Canal Orhei” and JSC "Apa-Termo" Ceadir-Lunga obtained positive results only for the Profitability from sales revenue calculated on the basis of net profit (net loss) indicator, influenced, in particular, by exchange rate differences, that is not an indicator which can be managed by the companies' corporate governance structures.

JSC "Operator Regional Apa-Canal" Hincesti holds 3 members on the Board of Directors, of which 1 is a employee of the water works company. The company provides services in 4 localities in addition to the town.

The weakest results of the profitability indicators were obtained by JSC "Regia Apa-Canal Soroca", with both indicators evolving on a strongly negative trend. The company's Board is composed of 5 members, all of whom are councillors.

The results of the study show that the participation in the company's board of employees from the water company has positive effects on the profitability of companies in the field of public water supply service.

\section{CONCLUSIONS AND RECOMMENDATIONS}

The companies in the field of water supply services are at the beginning of the path in the process of implementing corporate governance. Only 8 out of 40 water supply companies in urban areas in the Republic of Moldova are joint stock companies and the other companies have the municipal enterprise form of organisation as well as another form of organisation. The reorganisation into joint stock companies, in most cases, was imposed by signing agreements with international financing institutions but was not an intention manifested by local councils.

The positive effects of corporate management were identified in the JSC "Operator Regional ApaCanal" Hîncești company, which registered positive and growing profitability indicators and at JSC „ApăTermo" Ceadîr-Lunga, which recorded the highest growth rate in the Profitability of sales income calculated based on the net profit (net loss) indicator value. Both companies obtained a high score for the specific indicator of corporate governance Board diversity, which indicates that such an approach can lead to better profitability. But due to the fact that no performance indicators are established and the work of the Board is not evaluated, it is not possible, at this moment, to establish this relationship for certain. Applying the corporate management within JSC „Regia Apă-Canal Soroca” did not improve the economic situation. The company's results have worsened dramatically compared to the reference year - 2011. This company, in terms of uniform diversity, has a board composed of 5 members - all local councilmen. In the research process, the lack of adequate involvement of shareholders in the management of companies was identified. Because the shareholders of water companies are local councils, they manage public property and have no direct interest in the efficient management of companies. This is also demonstrated by the results obtained after analyzing the financial condition of water companies, based on the Altman model for the 2016 - 2018 period. This analysis identified that all 5 companies have a Z-score of less than 1.8, respectively they are unconditionally insolvent. A positive aspect is the evolution with a weak tendency to improve the Z-score for most companies, exept JSC „Apă-Canal Leova”. The participation of the water companies' employees in the company's board is not enough. Only in the case of 5 companies out of 8 in the Company's Board, at least one employee of the company is present. Likewise, there are no Supervisory Committees comprising company employees.

In order to improve the corporate management within the companies, in the field of public water supply services, the following recommendations are proposed:

1. To assess the effectiveness of the corporate governance process, water companies should develop a set of field-specific performance indicators which would form the basis for the evaluating the company's board and executive bodies work.

2. In the corporate governance process of companies in the field, the evaluation of the Company's Board must be carried out (for exemple, every 3 years) in order to control the efficiency of its activity. This includes the evaluation of its composition, organization and functioning as a group, of competence and effectiveness of each member and committee, as well as of results achieved in relation to the established objectives.

3. Signing the contracts of mandate with the Company's Board and with the executive bodies for the period was established with the indication of the development strategies of the water works companies and 
the specification of the performance indicators of their activity. Reporting on the fulfillment of performance indicators should be performed quarterly. The fulfillment of the performance indicators must directly influence the remuneration of the members of the Company's Board and of the executive bodies.

4. The Company's Board should comprise a sufficient number of independent professional members. In the case of analyzed companies, the independent members could be hired from other larger or better performing companies in the field.

5. Holding the General Meeting of Shareholders in compliance with all procedures established by law and internal regulations of the company.

6. Approval of the Corporate Governance Code [Decision of the National Commission of the Financial Market no. 67/10, 24.12.2015].

7. Formation of Basic Committees. The company's board should set up committees for the preliminary examination of the most important issues in the company's activity, such as the Remuneration Committee, the Risk Management Committee, etc.

8. Formation of the Supervisory Board within the Company's Board - this being a non-executive body with attributions to monitor the activity of the executive bodies [Ordonanța de urgență a României nr. 109/2011, 30.11.2011:5]. In addition, the development of the participation of water companies' employees in the company's board, including the establishment of Supervisory Committees composed of company employees.

The development of risk management practices. None of the analyzed companies have such regulations. Water companies may face risks, which can significantly affect a large part of the population of the Republic of Moldova, since the targeted companies operate critical infrastructure the disruption or destruction of which, can have a major devastating impact on both the population and business, in affected areas. In order to be effective and consistent, any risk management policy must be clearly established by the company's governing bodies.

The territorial administrative units in the area of which the joint stock companies manage the water supply service, must become shareholders of the company in order to participate in the management process of the water companies.

The public water supply companies operate under a natural monopoly, the shareholders are local councils and the customers are well known and do not have the option to choose another service provider, the high level of insolvency of companies which were calculated based on the Altman model, the maintenance in the last period of the losses from the operational activity, the non-participation of the adjacent administrative-territorial units in the management of the companies in which the service is managed, are factors that emphasize the need for continuous improvement of the respective companies' corporate governance framework.

\section{REFERENCES}

1. ALBU, N., DURICA, A., GRIGORE, N., GRIGORAȘ, D., MATEESCU, R., ICHIM, A. Guvernanța corporativă în România. Percepţii şi perspective. 2013, iunie. 42 p. [citat 15 martie 2020]. Disponibil: https://cig.ase.ro/wp-content/uploads/2013/04/Articol-guvernantacorporativa.pdf

2. ASOCIAȚIA "MOLDOVA APĂ-CANAL" (AMAC). Indicatorii financiari și de producție ai activității întreprinderilor de alimentare cu apă și de canalizare - membre ale Asociației "Moldova ApăCanal" pentru anul 2018. Chișinău, 2019. 107 p. [citat 16 martie 2020]. Disponibil: http://www.amac.md/doc.php?l=ro\&idc=29\&id=333\&t=/BULETINE-INFORMATIVE/Buletininformativ-AMAC/INDICATORII-financiari-si-de-productie-ai-activitatii-intreprinderilor-dealimentare-cu-apa-si-de-canalizare-membre-ale-Asociatiei-Moldova-Apa-Canal-anul-2018

3. ASOCIAȚIA "MOLDOVA APĂ-CANAL" (AMAC). Indicatorii financiari și de producție ai activității întreprinderilor de alimentare cu apă și de canalizare - membre ale Asociației "Moldova ApăCanal" pentru anul 2017. Chișinău, 2018. 107 p. [citat 17 martie 2020]. Disponibil: http://www.amac.md/doc.php?l=ro\&idc=15\&id=179\&t=/PRESA/Noutati/Indicatoriifinanciari-si-de-productie-ai-activitatii-intreprinderilor-de-alimentare-cu-apa-si-de-canalizaremembre-ale-Asociatiei-Moldova-Apa-Canal-anul-2017 
4. ASOCIAȚIA "MOLDOVA APĂ-CANAL" (AMAC). Indicii financiari și de producție ai activității întreprinderilor de alimentare cu apă și de canalizare - membre ale Asociației "Moldova ApăCanal" pentru anul 2016. Chișinău, 2017 [citat 18 martie 2020]. Disponibil: www.amac.md

5. ASOCIAȚIA "MOLDOVA APĂ-CANAL" (AMAC). Indicii financiari și de producție ai activității întreprinderilor de alimentare cu apă și de canalizare - membre ale Asociației "Moldova ApăCanal" pentru anul 2011. Chișinău, 2012. 107 p. [citat 19 martie 2020]. Disponibil: http://amac.md/Literatura/Sborniki/Analiz_indicii/Analiz_2011.pdf

6. ASOCIAȚIA "MOLDOVA APĂ-CANAL" (AMAC). Indicii financiari și de producție ai activității întreprinderilor de alimentare cu apă și de canalizare - membre ale Asociației „Moldova ApăCanal" pentru anul 2010. Chișinău, 2011. 108 p. [citat 20 martie 2020]. Disponibil: http://amac.md/Literatura/Sborniki/Analiz_indicii/Analiz_2010.pdf

7. ASOCIAȚIA "MOLDOVA APĂ-CANAL" (AMAC). Indicii financiari și de producție ai activității întreprinderilor de alimentare cu apă și de canalizare - membre ale Asociației "Moldova ApăCanal" pentru anul 2009. Chișinău, 2010. 97 p. [citat 20 martie 2020]. Disponibil: http://www.amac.md/Literatura/Sborniki/CD/02._Analiz_arhiva/Analiz_2009.pdf

8. AMBASADA BRITANICĂ LA CHIŞINĂU. Republica Moldova. Suport pentru Întreprinderile în proprietatea statului. Diagnosticul preliminar și evaluarea performanțelor în Republica Moldova. Etapa 1. 2017, martie. 101 p. [citat 02 aprilie 2020]. Disponibil: http://documents1.worldbank.org/curated/en/772311499413113949/pdf/117276-WPROMANIAN-P158220-PUBLIC-Moldova-Diagnostics.pdf

9. BOCĂNETE, O. Specificul evaluării eficienței economice a managementului corporativ din România. In: Studia Universitatis Moldaviae. Seria Ştiinţe exacte şi economice. 2013, nr. 2 (62), pp. 112-121. ISSN 1857-2073.

10. COMISIA EUROPEANĂ. Carte Verde, Cadrul de guvernanță corporativă al Uniunii Europene. Bruxelles, 2011 [citat 16 aprilie 2020]. Disponibil: https://eur-lex.europa.eu/legalcontent/RO/TXT/PDF, https://eur-lex.europa.eu/legalcontent/RO/TXT/?uri=CELEX\%3A52011DC0164

11. FELEAGĂ, N., FELEAGĂ, L., DRAGOMIR, V., BIGIOI, A. Guvernanţa corporativă în economiile emergente: cazul României. In: Economie teoretică şi aplicată. 2011, vol. XVIII, no. 9 (562), pp. 3-15. ISSN 1841-8678 [citat 12 aprilie 2020]. Disponibil: http://store.ectap.ro/articole/632_ro.pdf

12. Hotărîria Curții de Conturi, cu privire la Raportul auditului Proiectului „Programul de Dezvoltare a Companiilor de Aprovizionare cu Apă și Canalizare": nr. 29 din 22.07.2016. In: Monitorul Oficial al Republicii Moldova. 2016, nr. 342, art. 30 [citat 02 aprilie 2020]. Disponibil:http://www.ccrm.md/hotariri-si-rapoarte, https://www.legis.md/cautare/getResults?doc_id=95354\&lang=ro

13. Hotărîrea Comisiei Naţionale a Pieței Financiare cu privire la aprobarea Codului de guvernanță corporativă: nr. 67/10 din 24.12.2015. In: Monitorul Oficial al Republicii Moldova. 2016, nr. 4954, art. 363 [citat 23 aprilie 2020]. Disponibil: http://lex.justice.md/index.php?action=view\&view=doc\&lang=1\&id=363619

14. Apă Termo Ceadîr-Lunga [citat 23 aprilie 2020]. Disponibil: http://ceadir-lunga.apacanal.md

15. Servicii comunale Florești [citat 12 aprilie 2020]. Disponibil: http://floresti.apacanal.md

16. S.A. Operator Regional Apa-Canal Hîncești [citat 03 aprilie 2020]. Disponibil: http://hincesti.apacanal.md

17. Apă canal Leova [citat 23 aprilie 2020]. Disponibil: http://leova.apacanal.md

18. Apă canal Cahul [citat 12 aprilie 2020]. Disponibil: http://www.apacanalcahul.md

19. Apă canal Orhei [citat 21 aprilie 2020]. Disponibil: http://www.racorhei.md

20. Apă canal Chișinău [citat 03 aprilie 2020]. Disponibil: https://acc.md

21. BIROUL NAȚIONAI DE STATISTICĂ [citat 17 aprilie 2020]. Disponibil: https://statistica.gov.md/

22. COMISIA NAȚIONALĂ a PIEŢEI FINANCIARE [citat 29 aprilie 2020]. Disponibil: https://www.cnpf.md/ro 
23. IOVU, M. Guvernanța Corporativă în accepțiunea Organizației pentru Dezvoltare şi Cooperare Economică (OECD). 2019, 28 november [citat 23 martie 2020]. Disponibil:

https://www.linkedin.com/pulse/guvernanta-corporativa-acceptiunea-organiza\%C5\%A3ieipentru-iovu-ph-d

24. Legea Republicii Moldova privind societățile pe acțiuni: nr. 1134 din 02.04.1997. In: Monitorul Oficial al Republicii Moldova. 1997, nr. 38-39, art. 332 [citat 11 aprilie 2020]. Disponibil: https://www.legis.md/cautare/getResults?doc_id=111764\&lang=ro

25. Ordonanța de urgență a României privind guvernanța corporativă a întreprinderilor publice: nr. 109/2011 din 30.11.2011. Partea I. In: Monitorul Oficial. 2011, nr. 883 [citat 13 aprilie 2020]. Disponibil: http://legislatie.just.ro/Public/DetaliiDocument/133685

26. ORGANISATION FOR ECONOMIC COOPERATION AND DEVELOPMENT (OECD). G20/OECD Principles of Corporate Governance. Paris: OECD Publishing, 2015. 58 p. ISBN 978-92-6423687-5 [citat 18 martie 2020]. Disponibil: http://dx.doi.org/ 10.1787/9789264236882-en, http://www.oecd.org/corporate/

27. Statutul Societății pe Acțiuni "Apă-Canal Chișinău". Aprobat prin Adunarea Generală a Acționarilor, Procesul-Verbal nr. 9 din 18 ianuarie 2008, cu modificările ulterioare. Chișinău, 2008. 24 p. [citat 15 martie 2020]. Disponibil:

https://www.chisinau.md/public/files/strategice/strateg_vas/apa_canal/Statut_SA_Apa_Canal. pdf

28. UNIUNEA EUROPEANĂ, GUVERNUL ROMÂNII. Manualul Naţional al Operatorilor de Apă și Canalizare. Programul FOPIP 1 - Asistența Tehnică pentru Consolidarea Instituțională a Beneficiarilor Finali ISPA din cadrul sectorul de Apă si Apă Uzată. București, 2008. 288 p. [citat 10 aprilie 2020]. Disponibil:

file:///C:/Users/ANGELA 1.CAT/AppData/Local/Temp/27848_md_manua_operator_a.pdf

\section{ARTICLE HISTORY}

Received 29 May 2020

Accepted 23 October 2020 